UDK 622.287

Yu. M. Khalymendyk ${ }^{1}$, Dr. Sc. (Tech.), Prof., orcid.org/0000-0003-3308-0783,

V. Yu. Khalymendyk ${ }^{1}$, orcid.org/0000-0002-0041-0283, L. M. Zakharova ${ }^{2}$, Cand. Sc. (Tech.), orcid.org/0000-0003-2135-5567, V.V.Nazimko ${ }^{3}$, Dr. Sc. (Tech.) Prof., orcid.org/0000-0003-3154-2745

\title{
BENCH TESTING OF A STEEL YIELDING FRAME SUPPORT
}

The problem of stability maintenance for underground workings becomes more urgent as the depth of mining increases. Currently, combination of rock bolts or cables and steel frames has become popular among practitioners. Manufacturer use such support for providing entry stabilities in complex geologic environments. However, the number of publication concerning testing of steel frame yielding support is limited, especially benchmark testing when parameters of the frame are controlled in laboratory and may be monitored comprehensively.

Purpose. To establish variation regularities of resistance and steel yielding arches during its benchmark testing.

Methodology. Methods are based on thermodynamics of irreversible processes and consideration of interactions of the adjacent frames and their elements when under the ground pressure. We employed the probability theory and mathematical statistics to investigate these regularities.

Findings. It was found that fluctuations of the frames resistance and their yielding provide a lot of important information concerning non-linear behavior of metal support systems. We have done spectral and correlation analysis to investigate parameters of the fluctuations and proved that the yielding occurs in an anti-phase mode.

Originality. It was the first time when spectral characteristics of the frame resistance and yielding fluctuation have been determined as well as the fact that resistance of adjacent frames and their structural elements is realized in an anti-phase mode.

Practical value. Necessity to improve frame support systems by decreasing the fluctuation period of resistance to ground pressure and yielding was substantiated. Possible range of fluctuation of yielding and resistance were justified.

Keywords: frame yielding support, irreversible deformation, fluctuation of the frame resistance, spectral characteristics, mine

Introduction. Extractive industries provide stable energetic and material resource independence for our country. There are steady tendencies for increasing segment of underground extraction because of exhausting of reserves at the shallow depths, which is typical trend in the world [1].

Such conditions rise the urgency of providing stability maintenance of underground roadways, because increase in the mining depth is not in pace with the progress in technologies that enhance stability of the roadways. The most popular technology that expanded in the extracting industries of the USA, Australia and the SAR is the rock bolting, which has been used to support the roof of the roadways since the 60s. However, using rock bolts only cannot provide stability of the roadways, when the depth of mining growths essentially and displacements of the surrounding rocks increased from several millimeters up to one meter and even more. That is why specialists of the countries having well-developed extractive industries continue research works and try to improve designs of the yield frame support.

Prusek et al. presented expanded synopsis of the state of the frame support designs that are used for the maintenance of the underground entries in the coal extraction industry in Poland and the Czech Republic [2]. They proved the necessity for improvement of a support that is a combination of rock bolts and yielding frames. The same

(C) Khalymendyk Yu. M., Khalymendyk V. Yu., Zakharova L. M., Nazimko V.V., 2018 problem is urgent in China coal industry [3]. For example Zhibiao et al., admit that there is not effective relevant support that would provide stability of the roadways in complex geologic environment and great depth of mining [4].

German specialists concluded that it is impossible to maintain underground roadways at the depth of $900 \mathrm{~m}$ without combination of the frame support and the rock bolts or cables [5].

Despite the fact that the rock bolting technology is popular in Great Britain, their specialists consider improvement of frame supports as a necessary element for development of future extracting industries [6].

American operators consider need for standing support implementation, especially in the longwall face because the rock bolts cannot maintain entry stability behind the longwall independently [7].

The scientists investigate efficiency of the frame support both in an underground environment and with computer simulation. They use testing of the frames in special laboratory installations episodically, because sizes of the frames reach up to $5 \mathrm{~m}$ and the testing equipment is expensive and bulky.

There are few publications [8] that report limited information concerning testing of the frames at laboratory installations. As usual, specialists reduce the testing data down to dependence of the frame resistance on its yield. However, the frames demonstrate essentially nonlinear behavior, when several resistance may correspond to one yield value. This peculiarity did not find a relevant response in the technical literature. 
Nevertheless, this nonlinear behavior is the main feature, which facilitates adaptation of the frame support to the ground pressure intensive manifestation. Let us stress that testing of the frames on laboratory equipment provides much more advantage including accuracy, and wide array of the experimental data.

Therefore, the aim of this paper was to investigate these peculiarities with the bench tests on special laboratory equipment.

Substantiation of the methodology of laboratory testing. There are several schematics of testing frame support on the laboratory equipment. The simplest mode of testing is to investigate a clutch on two straight overlapping pieces of profile. Actually, it is a yielding prop, which is installed under loading hydraulic machine. Hydraulic mechanism loads the prop and the clutch yield allowing sliding each piece relatively other.

However, contact of the pieces in arch frame support is not linear. That is why majority of procedures test one frame, which lay on the horizontal floor [8]. Experimenters install a special testing frame around frame support being tested. They place rams between the testing frame and tested frame support (Fig. 1, c). The rams provide loading of the frame.

All degrees of freedom should be restricted except those translations in the horizontal plane and rotations around normal to this plane. The frame produces maximal resistance in such boundary conditions. However, the actual situation that occurs in the underground environment differs essentially from such ideal boundary conditions.

That is why we have employed a method when two adjacent frame supports are tested. This technique was developed in Donetsk State Scientific and Research Coal Institute ("DonUGI") [9] and allows simulating behavior of the yielding frame support that is the closest to reality in underground mines. Adjacent frames have much more degree of freedoms and may deviate from theoretical path of resistance to ground pressure.

Figs. 1 and 2 show dependence of the first and second frame resistance on the corresponding yield of these frames. In addition, Fig. 2 depicts the loading scheme of the adjacent tested frames. These results were extracted from the protocol [9].
Advantage of the testing methodology includes simultaneous testing of both the first and the second adjacent frames that were connected with struts as in a real underground roadway. According to [9], rams 1 and 3 loaded frame No. 1 whereas rams 2 and 4 applied load to frame No. 2. Hydraulic rams were installed symmetrically relative to vertical axis of the frames at the distance of $1 / 3$ of the frame width. The experimenters used special profile SVP27 during assembling of the frames. The area of vertical section of the frames was $13.8 \mathrm{~m}^{2}$. The distance between adjacent frames was $0.8 \mathrm{~m}$, which is typical for deep coalmines that extract coal at the depth of 700-800 $\mathrm{m}$ and deeper.

During testing, resistance of the frame was monitored with special registers and yielding of the frames periodically was measured with leveling of the arch member apex.

Despite continuous monitoring, the experimenters used few data from the array. Only six points were selected from the general statistical sampling (Figs. 1, $a, b$ ). All data were averaged and smoothed. Only limited conclusion was drawn from these data. For example, frame resistance was proportional to yield, and maximum of the resistance was $350 \mathrm{kN}$ for the yield of $100 \mathrm{~mm}$ (Fig. 1, a). Further attempt to increase the load caused plastic deformation of the tested frame.

According to our opinion, potential information of the testing was underused essentially. We considered the set of the frame and rams as a thermodynamic system that goes through irreversible processes of plastic deformation of the frame metal and reciprocal sliding of the frame members, which dissipate energy of ground pressure.

According to [10], dissipative structures should occur in this system and the structures may variate in time and space. We digitized the monitored data and constructed diagrams that reflect variation of the frame resistance in time (Fig. 2). One unit of time corresponds to ten seconds. Overall duration of the testing was approximately half an hour.

Maximum resistance of the clutches were $200 \mathrm{kN}$ when yield of the frames reached $110 \mathrm{~mm}$. The resistance of the frames grew steadily while yield accumulated approximately to $80-100 \mathrm{~mm}$. The experimenters declared maximum bearing capacity of the frames at the level of $350 \mathrm{kN}$ (Fig. 1, b). However, this result has been calculated as the sum of resistance of a rams' pair. Such bearing capacity may be realized if the clutches would
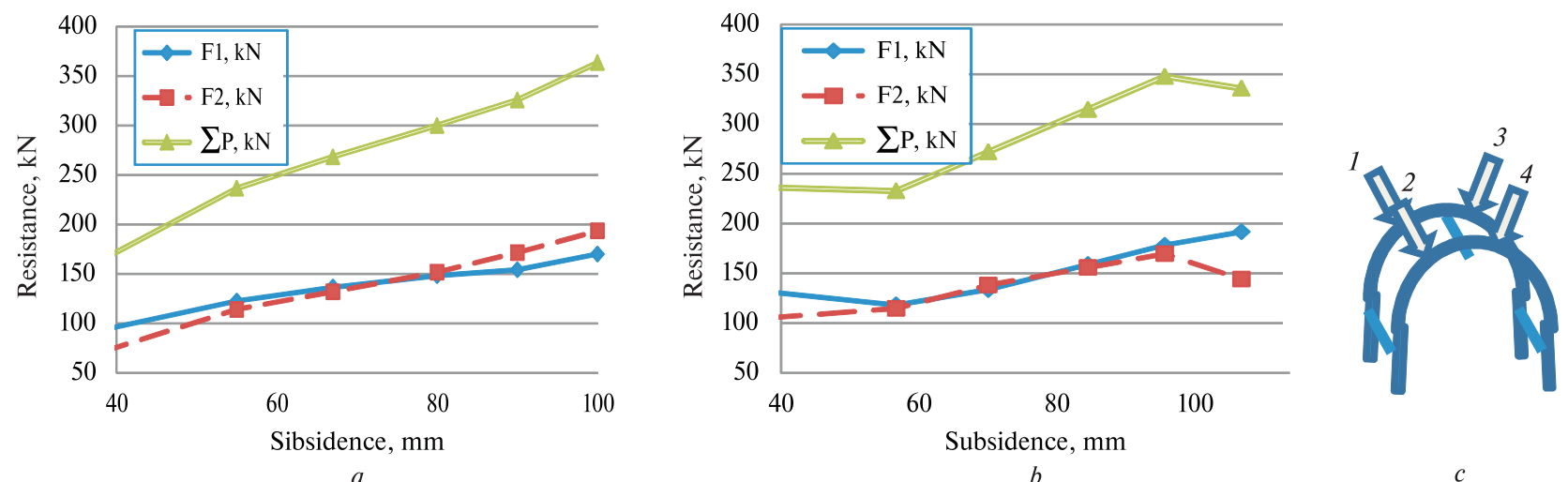

Fig. 1. Dependence of resistance on the yield for frame (a) and (b):

$c$ - schematic of the testing; $1-4-$ number of the rams 


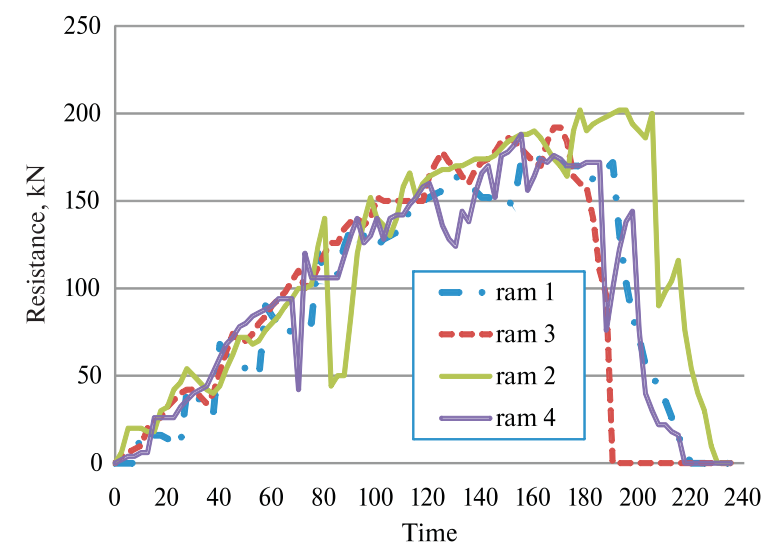

Fig. 2. Dynamics of ram resistance

yield synchronously. However, it was not the case.

Results of the investigation. The resistance of the frames varied in the time essentially, periodically raising and falling due to yielding of the clutches. Diagrams of the resistance are not linear. As the resistance variation has explicit stochastic character, we made spectral analysis of the resistance fluctuation. We selected linear interval of the frames behavior within 180 time units while the frames saved stability.

Diagram of spectral density in Fig. 3 shows that the most popular period between subsequent yields variates in the range from 10 to 30 units that corresponds to $10 \mathrm{~mm}$ of the frame subsidence or $2-5 \mathrm{~mm}$ reciprocal sliding of the frame members in the clutches.

According to distribution in Fig. 4, the main fraction of ground pressure energy (or ram pressure) dissipates by small elementary yields. It means essential differentials of the frame resistance both as magnitude of resistance and as yield amplitude are not suitable, because they do not dissipate the energy of ground pressure. In addition, they increase probability of jamming of the clutches and loss of bearing capacity of the frames.

We constructed diagram of averaged statistical sampling (Fig. 5) where nonlinearity is manifested much better. Nonlinearity begins from 80 units of time and further. This moment is marked with an arrow. Trend of the nonlinear behavior has been described by polynomial function of the forth order with confidence of 0.95 . To offload residual error, we calculated resistance variance from current averaged value using this polynomial function. The variation of the resistance has been calculated at every time point along the statistical polynomial curve as difference between averaged value and measured.

Fig. 6 demonstrates diagram of the variation for all the rams during the experiment. As may be seen, magnitude of the variation does not depend on the current value of the resistance. In addition, maximal deviation of the resistance from average trend occurred at the moment of 80 time units, and the deviation happened to the both sides.

Such an effect may cause jamming of the clutches. Symptomatically, there was a warning jamming at the moment of 70 time units. Linear dependence between resistance and yield was broken after 80 time units or 50-70 $\mathrm{mm}$ yield of the clutches.

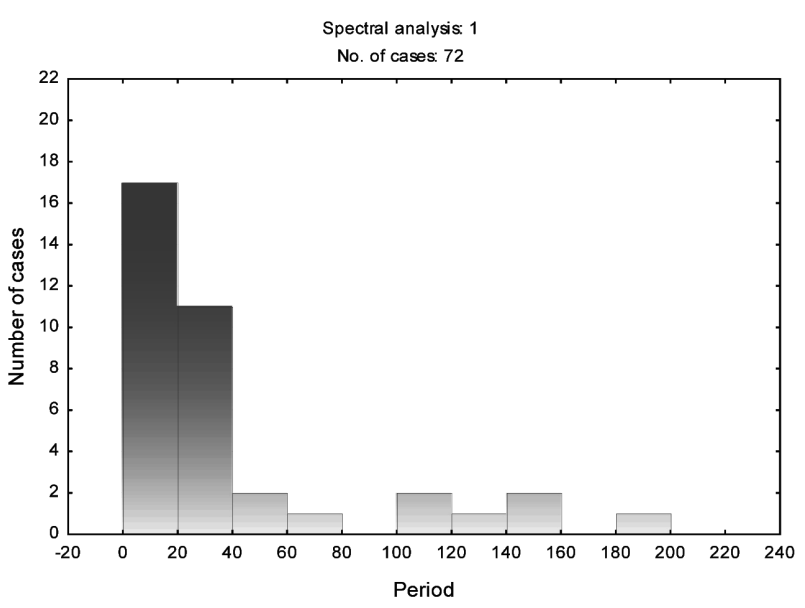

Fig. 3. Histogram of yielding period

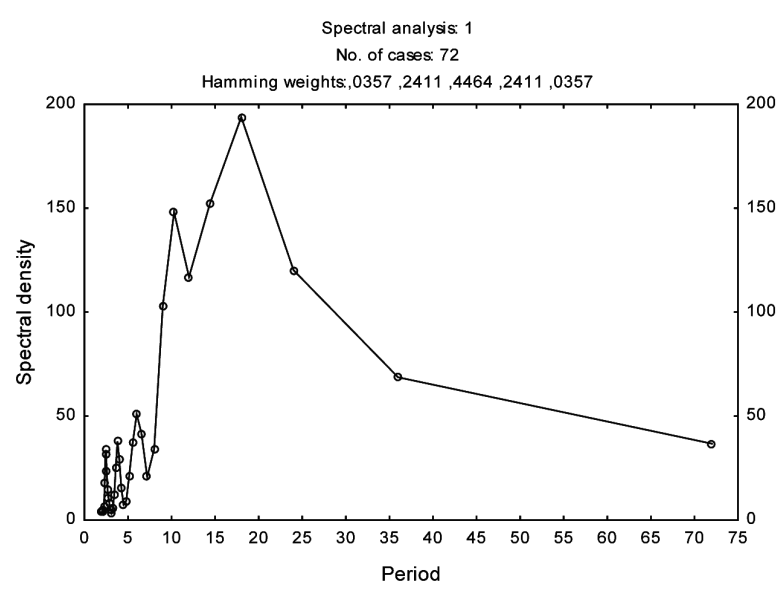

Fig. 4. Distribution of spectral density

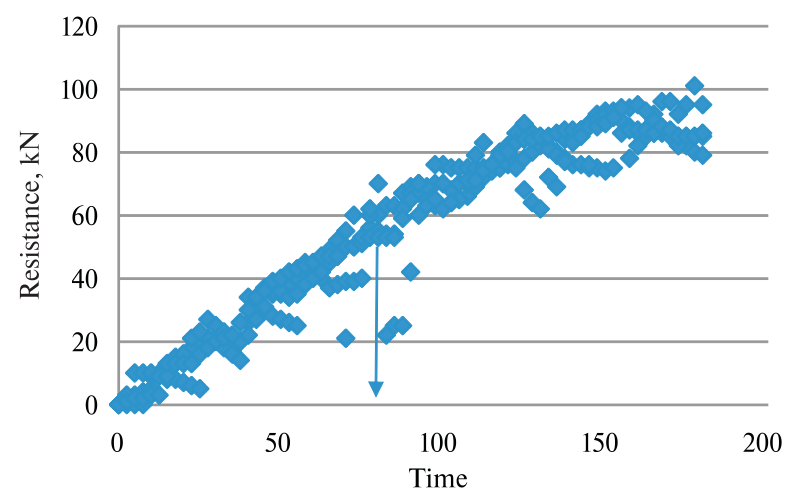

Fig. 5. Overall sampling data

Fig. 7 demonstrates histogram of the stochastic resistance variation, which corresponds to normal distribution with standard of $\pm 11.9 \mathrm{kN}$ or $6.7 \%$ from normal resistance of a clutch. Absolute magnitude of the frame resistance variation varied from $30 \mathrm{kN}$ up to $56.5 \mathrm{kN}$ or five times more than standard variation and is $1 / 3$ of maximum resistance that was $178 \mathrm{kN}$. Such magnitude is dangerous and can cause jamming of the clutches and loss of the frame stability.

Digitizing of the experimental data has been accomplished in the same moments of times for all the clutch- 


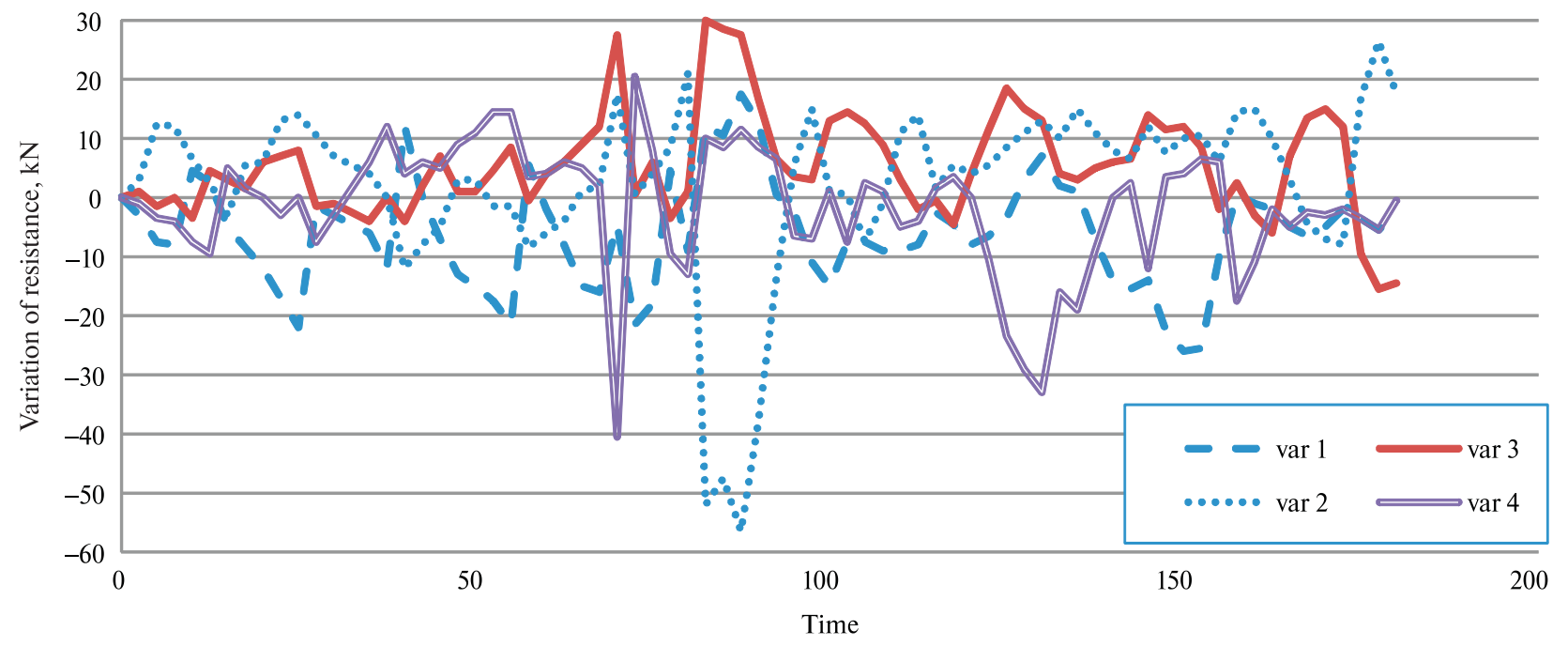

Fig. 6. Distribution of spectral density

es (rams) that allowed calculating the correlation (Table). There may be six permutations between pairs among four rams. Correlation analysis attests that four permutations from the six demonstrate essential relationship (correlation factors highlighted by italic), and signs of the factors are negative.

It means that when a ram increases its load (in the other words, a clutch increases its resistance) adjacent rams (clutches) reduce their opposing force and vice versa.

Therefore, the frames and even the clutches yield in turn, one after another in order to minimize their work spending for the dissipation of the ground pressure. Such behavior reduces efficiency of the frame support. This conclusion is in a good agreement with the deductions concerning interaction of the rock mass clusters [11]. Failure zone around an underground roadway expanded asymmetrically, by discrete portions in time and space. That complements the picture of dissipative structures that occur in the "underground roadway support - surrounding rock mass" system. In fact, surrounding rock mass and yielding frame support interact

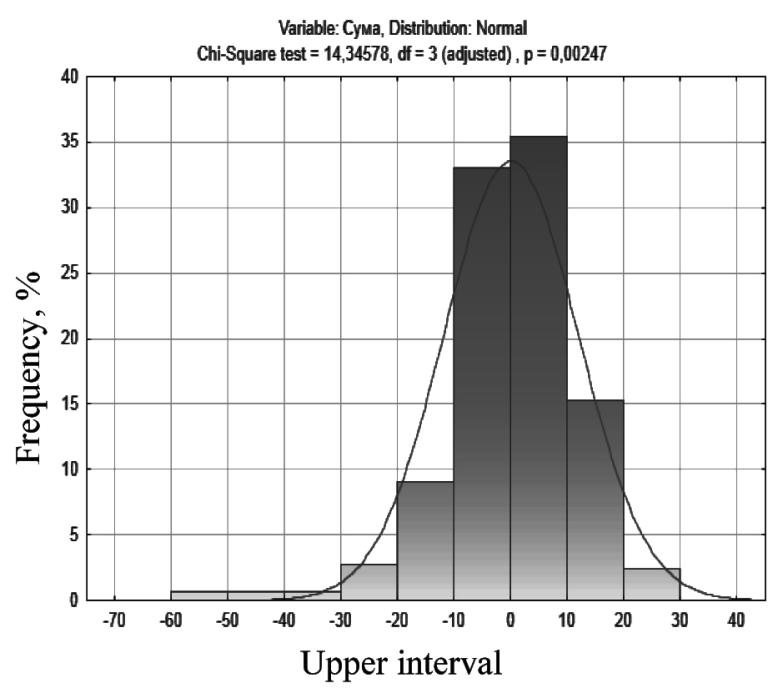

Fig. 7. Histogram of resistance variation in such a way, that to minimize their resistance using sequential yielding of the frame clutches.

Such behavior reduces bearing capacity of the frames, what diminishes their efficiency.

Discussion. The mechanism of stability deterioration is complex and was explained by [12]. The "underground roadway - yielding support - surrounding rock mass" combination is a thermodynamic system that transits to irreversible state under action of ground pressure. This transition causes spontaneous generation of the so-called dissipative structures that disseminate ground pressure energy transforming it into irreversible ground movement, heat and surface energy of the fractured rock mass.

The dissipative structures are relatively stable shortliving formations that self-organize themselves in time and in space as specific patterns [13]. The most persistent patterns of the ground are rotors and structural torrents, whereas yielding frame support generates autofluctuation and antiphase yield of clutches. In addition, the frames spatial structures such as longitudinal plastic rotation of their profile, turning out their props, and collective inclination.

Such a specific behavior of the frame support provokes asymmetric development of damaged rock mass around the underground roadway. Boundaries of the damaged zone expand asymmetrically in space and sequentially or by turn in time. Such irreversible ground behavior creates ground dissipative structures that are in concordance with the dissipative structures of yielding support.

Table

Correlation factors between pairs

\begin{tabular}{|c|c|c|c|c|c|c|}
\hline & & & \multicolumn{4}{|c|}{ Ram number } \\
\hline & Average & Standard & 1 & 3 & 2 & $\mathbf{4}$ \\
\hline 1 & -3.09 & 4.54 & 1.00 & 0.11 & $-\mathbf{0 . 4 8}$ & $-\mathbf{0 . 2 7}$ \\
\hline 3 & 2.72 & 4.42 & 0.11 & 1.00 & $-\mathbf{0 . 5 8}$ & -0.11 \\
\hline 2 & 1.21 & 7.41 & $-\mathbf{0 . 4 8}$ & $-\mathbf{0 . 5 8}$ & 1.00 & $-\mathbf{0 . 4 9}$ \\
\hline 4 & -0.84 & 5.35 & $-\mathbf{0 . 2 7}$ & -0.11 & $-\mathbf{0 . 4 9}$ & 1.00 \\
\hline
\end{tabular}


To be more specific, a feedback occurs between the support dissipative structures and the ground dissipative structures. Such concordance deviates both frame supports and surrounding rock mass from active resistance to ground pressure, shifting the mode to passive inefficient opposition.

Therefore, practitioners should employ special technologies for suppression of such dissipative structures and control ground pressure by efficient methods.

According to [12], the most efficient technologies that suppress the dissipative structures in the surrounding underground roadway rock mass are: combination of yield frame support and rock bolts or cables, combination of rock cables and yielding props, injection of resin in fractured rock mass, installation of pretensioned rock bolts and cables, distressing of surrounding rock, using struts between adjacent rock bolts.

These devises and technologies prevent close interaction of rock fragments and clutches of the yielding frame support as well as distant cooperation of dissipative structures.

Therefore, our investigation allows delineating next prospective ways of frame support improvement.

1. We should provide such regime of clutch yielding, when variation of the resistance does not exceed $6.7 \%$ from average level of this resistance.

2. Elementary yield of a clutch should not exceed $5-7 \mathrm{~mm}$.

3. We need to provide even, steady and synchronic yield among adjacent clutches. In other words, all adjacent clutches should yield on the same sliding distance and at the same time at least in the limits of a frame.

Conclusion. Bench testing of two adjacent frame yield supports demonstrated that the frame resistance variated essentially. The frames reduced their dimension in time by portions or by elementary yields. Typically, a clutch periodically yielded to $2-5 \mathrm{~mm}$ that reduced vertical dimension of a frame by 7-10 mm. Spectral density analysis demonstrated that such elementary yields dissipate the main fraction of energy spent by testing equipment.

Clutches yield by turn, one after another, raising resistance due to jamming and loosing opposing force after yielding periodically. Consequent work of the clutches has been found using statistical analysis. Correlation factors of resistance correlation among adjacent clusters was negative with significant confidence, what corroborates that adjacent clutches coordinate their activity triggering by turn. Such behavior reduces efficiency of the frame functioning and decreases their bearing capacity.

Large variations of the frame resistance and their yield are not useful because they do not dissipate ground pressure energy and provoke jamming of the clutches, what may diminish bearing capacity of the frame support.

Nonlinear behavior of the frame starts from the first jamming of the clutches that produces increase in resistance deviation relative to standard fluctuation by factor five. Such jamming generates plastic deformation of the clutches, and frame resistance falls behind the yielding rate.

New approach to improvement of yielding frame support employs restriction of frame resistance variation, its elementary periodic yield, and elimination of asynchronous yielding of adjacent clutches both within a frame and between adjacent frames.

\section{References.}

1. Pivnyak, G. G. and Shashenko, A. N., 2015. Innovations and safety for coal mines inUkraine. Naukovyi Visnyk Natsionalnoho Hirnychoho Universytetu, 6(150), pp. 118-121.

2. Prusek, S., Lubosik, Z., Dvorsky, P. and Horak, P., 2012. Gateroad Support in the Czech and Polish Coal Mining Industry - Present State and Future Developments. In: Proc. $30^{\text {th }}$ International Conference on Ground Control in Mining. WVU, Morgantown [online], pp. 101-111. Available at: <https://icgcm.conferenceacademy.com/ papers/allpapers.aspx $>$ [Accessed 17 September 2017].

3. Renshu, Y., Yongliang, L., Dongming, G., Lan, Y., Tongmao, Y. and Taotao, L., 2017. Failure mechanism and control technology of water-immersed roadway in highstress and soft rock in a deep mine. International Journal of Mining Science and Technology, 27, pp. 245-252.

4. Zhibiao, G., Jiong, W. and Yuelin, Z., 2015. Failure mechanism and supporting measures for large deformation of Tertiary deep soft rock. International Journal of Mining Science and Technology, 25, pp. 121-126.

5. Stahlmann, J., Missal, C. and Edel, T., 2013. Geotechnical conditions at the Konrad mine - Excavation of drifts and rooms in squeezing rock. Geotechnische Bedingungen in der Schachtanlage Konrad - Auffahrung von Strecken und Kammern in druckhaftem Gebirge. Mining Report, 150(5), pp. 250-338. DOI: 10.1002/mire.201400029.

6. Ma, K.J. and Stankus, J., 2018. Case Study and Design of Steel Set Support for Aged Belt Entry Rehabilitation, International Journal of Mining Science and Technology, 28(1), pp. 101-106. DOI: 10.1016/j.ijmst.2017.12.025.

7. Batchler, T., 2017. Ten Factors About Standing Supports That Might Surprise You. In: Proc. $36^{\text {th }}$ International Conference on Ground Control in Mining, WVU, Morgantown [online], pp. 115-120. Available at: $<$ http://smemi.personifycloud.com/PersonifyEbusiness $/$ Default.aspx?TabID $=251 \&$ productId $=1840324>$ [Accessed 4 December 2017].

8. Xie, W. and Wang, X., 2015. Structural Stability of U-Steel Frame and Its Control Technology. In: Proc. $34^{\text {th }}$ International Conference on Ground Control in Mining. WVU, Morgantown [online], pp. 108-114. Available at: <http://smemi.personifycloud.com/PersonifyEbusiness $/$ Default.aspx?TabID $=251 \&$ product Id $=1840324>$ [Accessed 4 December 2017].

9. Kompanets, V. F., 2000. Protocol of bench testing of yielding frame support AP3 having section area of $13.8 \mathrm{~m}^{2}$. Donetsk: DonUGI.

10. Kondepudi, D. and Prigogin, I., 2015. Modern thermodynamics: from heat engines to dissipative structures. $2^{\text {nd }}$ ed. John Wiley and Sons; XXVI, 524.

11. Griniov, V., Zakharova, L., Diedich, I. and Nazymko, V., 2017. Distant interaction of rock mass clusters around underground opening. Mining of Mineral Deposits, 11(2), pp. 43-46.

12. Nazimko, V. V. and Zakharova, L. M., 2017. Cluster behavior of the ground during its irreversible movement. 
Acta geodynamica et geomaterialia, 14(188), pp. 45-49. 13. Zakharova, L., 2017. Generating of dissipative structures during ground irreversible movement. Transactions of Kremenchuk Mykhailo Ostrohradskyi National University, 8(105), pp. 118-122.

\section{Стендові випробування сталевого піддатливого рамного кріплення}

\section{Ю. М. Халімендик ${ }^{1}$, В. Ю. Халімендик ${ }^{1}$, Л. М. Захарова ${ }^{2}$ В. В. Назимко}

1 - Державний вищий навчальний заклад „Національний гірничий університет“, м. Дніпро, Україна, e-mail: khalymendyk@meta.ua

2 - Інститут фізики гірничих процесів НАН України, м. Дніпро, Україна

3 - Інститут фізики гірничих процесів НАН України, м. Миколаїв, Україна, е-mail: victor.nazimko@gmail.com

Проблема підтримання стійкості підземних виробок стає все більш актуальною в міру поглиблення шахт. На поточний момент, найбільш популярним серед практиків стало комбіноване рамно-анкерне кріплення. Виробничники застосовують таке кріплення для забезпечення стійкості виїмкових штреків у складних гірничо-геологічних умовах розробки родовищ корисних копалин. Проте число публікацій стосовно випробування рамного піддатливого сталевого кріплення обмежене, особливо в лабораторних умовах, коли є можливість зареєструвати результати тестування детально й ретельно.

Мета. Встановити закономірності варіації опору й піддатливості рамного кріплення під час його стендового випробування.

Методика. Базується на термодинаміці необоротних процесів і врахуванні взаємодії суміжних рам та їх елементів під час дії гірського тиску. У роботі застосовувалися теорія ймовірності й методи математичної статистики для виявлення вказаних закономірностей.

Результати. Встановлено, що флуктуації опору рам та їх піддатливості містять об'ємну й важливу інформацію щодо нелінійної поведінки систем металевого кріплення. Виконано спектральний і кореляційний аналізи параметрів флуктуацій і доведено, що піддатливість суміжних рам реалізується у протифазному режимі.

Наукова новизна. Уперше встановлені спектральні характеристики варіацій опору й піддатливості рамного кріплення, а також доведено, що опір поряд стоячих рам та їх конструктивних елементів реалізується у протифазному режимі.

Практична значимість. Полягає в обгрунтуванні необхідності вдосконалення систем рамного кріплення в напрямі зменшення періоду флуктуацій величини опору гірському тиску й піддатливості. Обгрунтовані допустимі діапазони флуктуації піддатливості та опору.

Ключові слова: рамне піддатливе кріплення, необоротні деформації, варіації опору, спектральні характеристики, шахта

\section{Стендовые испытания стального податливого рамного крепления}

\author{
Ю. М. Халимендик ${ }^{1}$, В. Ю. Халимендик ${ }^{1}$ \\ Л. Н. Захарова ${ }^{2}$, В. В. Назимко
}

1 - Государственное высшее учебное заведение „Национальный горный университет“, г. Днепр, Украина, e-mail: khalymendyk@meta.ua

2 - Институт физики горных процессов НАН Украины, г. Днепр, Украина

3 - Институт физики горных процессов НАН Украины, г. Николаев, Украина, e-mail: victor.nazimko@gmail.com

Проблема поддержания устойчивости подземных выработок становится все более актуальной по мере углубления шахт. На текущий момент, наиболее популярной среди практиков стала комбинированная рамно-анкерная крепь. Производственники применяют такое крепление для обеспечения устойчивости выемочных штреков в сложных горно-геологических условиях разработки месторождений полезных ископаемых. Однако число публикаций относительно испытания рамного податливого стального крепления ограничено, особенно в лабораторных условиях, когда есть возможность зарегистрировать результаты тестирования подробно и тщательно.

Цель. Установить закономерности вариации сопротивления и податливости рамного крепления во время его стендового испытания.

Методика. Базируется на термодинамике необратимых процессов и учете взаимодействия смежных рам и их элементов во время действия горного давления. В работе применялись теория вероятности и методы математической статистики для выявления указанных закономерностей.

Результаты. Установлено, что флуктуации сопротивления рам и их податливости содержат объемную и важную информацию о нелинейном поведении систем металлической крепи. Выполнен спектральный и корреляционный анализы параметров флуктуаций и доказано, что податливость смежных рам реализуется в противофазном режиме.

Научная новизна. Впервые установлены спектральные характеристики вариаций сопротивления и податливости рамного крепления, а также доказано, что сопротивление рядом стоящих рам и их конструктивных элементов реализуется в противофазном режиме.

Практическая значимость. Заключается в обосновании необходимости совершенствования систем рамного крепления в направлении уменьшения периода флуктуаций величины сопротивления горному давлению и податливости. Обоснованы допустимые диапазоны флуктуации податливости и сопротивления.

Ключевые слова: рамная податливая крепь, необратимые деформации, вариации сопротивления, спектральные характеристики, шахта

Рекомендовано до публікації докт. техн. наук О. С. Кучиним. Дата надходження рукопису 25.06.17. 